\title{
The Instructional Simulation in the Business Environment and Attitude towards Entrepreneurship in Improving Oral Communication in English
}

\author{
Eva Perea Muñoz \\ VAnesa Berlanga Silvente \\ JoAN Ripoll AlcóN \\ Universidad Abat Oliba CEU
}

Received: 1 April 2016 / Accepted: 12 August 2016

ISSN: $1697-7467$

\begin{abstract}
This article is an empirical study to analyze the oral production in English by simulation as a teaching instructional strategy among college students of Business Management at the University Abat Oliba CEU. A design group pre-test and post-test in the overall assessment of oral expression variable is used. Quantitative data on progress and contribution to learning English with the simulation were collected in a questionnaire online. The results show how the instructional simulation and the use of new technologies are effective tools in the acquisition of language skills in English.

Keywords: Higher education, Instructional simulations, communicative competence, English learning

La simulación instruccional en el entorno empresarial y la actitud hacia el emprendimiento en la mejora de la comunicación oral en lengua inglesa

RESUMEN: Este artículo trata de un estudio empírico dirigido a analizar la producción oral en lengua inglesa mediante la simulación instruccional como estrategia docente entre los estudiantes universitarios de Dirección de Empresas de la Universitat Abat Oliba CEU. Se empleó un diseño de grupo de pre-test y post-test en la evaluación global de la variable expresión oral. Los datos cuantitativos sobre el progreso y la contribución al aprendizaje del inglés con la simulación fueron recogidos en un cuestionario on-line. Los resultados muestran cómo la simulación instruccional y el uso de nuevas tecnologías constituyen herramientas eficaces en la adquisición de la expresión oral en lengua inglesa.

Palabras clave: Educación superior, Simulaciones instruccionales, competencia comunicativa, Aprendizaje del inglés
\end{abstract}

\section{INTRODUCTION}

According to some organizations and institutions, such as the Organization for Economic Cooperation and Development (OECD) it is increasingly necessary to produce competent 
professionals strong in knowledge, skills, attitudes and values. In this sense, universities must put in place the necessary mechanisms to help students with the tools and practices necessary, not only to achieve a level of proficiency in the language that will allow them to communicate effectively, but also to ensure sure that transversal competences form part of the teaching and learning process (Angelini, García-Carbonell and Martinez, 2015). According to the authors, communication skills, teamwork, professional ethics, expertise within a global and social industry, continuous learning and general knowledge of current issues are required to meet the needs of the productive sector.

According to Brookfield (1983), instructional simulation or experiential learning is a form of learning that "offers students the opportunity to acquire and apply knowledge and skills in an immediate and relevant context." In this way students are in direct contact with what they are going to learn rather than just thinking about it.

Moreover, at present, educational institutions are engaged in addressing important challenges related to motivation and commitment by students. One of the most common reasons for underachievement is distraction and disconnection when using state of the art technologies among students and teachers (Aranda, Sánchez and Djundubaev, 2016). In this sense, attention levels fall if these methods become routine for students. Tools such as instructional simulations in business environments are becoming broadly accepted educational strategies thanks to the potential they offer in increasing students' motivation and commitment (Domínguez, Saenz-de-Navarrete, De-Marcos, Fernández-Sanz, Pagés, and Martínez-Herráiz, 2013; Aranda Sánchez and Djundubaev, 2016).

In this sense, Ros and Conesa (2013) analyzed how teaching methods must readapt to the new demands of the professional environment, something which has become the new challenge of higher education. Teaching methods and procedures should not be focused on the transmission of information but on the promotion of individual competencies (Romero, 2010; Santos, Alarcón and Pablo, 2016). Teaching and learning methods must be adapted, with the objective of enabling learners to acquire skills related to the professional profiles of a degree. The teacher's task goes from being a mere transmitter of knowledge, to becoming the manager of the learning process of students; the lecturer must choose between different teaching methods depending on the type of skills that are to be developed, the characteristics of the group and the potential of the scenario where the activity will take place (De Miguel, 2006a, 2006b; Santos, Alarcón and Pablo, 2016).

All this can only be achieved through the application of techniques or tools that can help students to put knowledge into practice. The purpose is to incorporate into the teaching practice of higher education both experiential learning (based on experience) and experimental learning (based on experimental practices) in order to meet new training demands. Within learning through experience we can include role play and instructional simulation (Clemente and Perez, 2013).

Instructional simulation introduces students into a scenario that addresses issues either of their specialty or of global interest. The participants, divided into teams, carry out the analysis of this reality, negotiate positions, take decisions, resolve issues and reflect on the experience. In this way, therefore, simulation methodology facilitates the acquisition of 
expertise while enabling interacting, communicating, leading, negotiating and working in teams, in real contexts, as Blasco (2000), García-Carbonell, Watts Hooge and Andres Andreu (2012), Clemente and Perez (2013) make clear.

In a role play or a dramatization, students act, taking on roles that would not be their own under normal circumstances. The emphasis is on the actual "play", i.e., in playing a certain role or mimicking certain behaviour over a short period of time and, generally, with some previously established set of information.

However, in a situational simulation or experiential learning, students take on different duties and responsibilities while still being themselves. In simulation, the participants are not actors, so they take decisions they consider appropriate to best meet the situation they are in, as they would in real life. In this sense, Aranda, Sánchez and Djundubaev (2016) include, among other advantages for the student, the ability to implement theoretical knowledge, to resolve conflict management and to become involved in making complex strategic decisions, thus increasing student motivation.

There is, then, a default scenario or contextualization, but the final decision always rests in the students' hands. Hence, having to make decisions, different groups involved in the same situation suggest different conclusions. Accordingly, an instructional simulation is usually open ended. Thus, it is possible to integrate specialized contents with the development of professional skills (Angelini, García-Carbonell and Martinez, 2015), largely because, as Crawford (2003) points out, an instructional simulation is not a mechanical exercise, but " a way to bounce our ideas and values against reality and see how they bounce back".

In this context, oral communication is essential in the business world, not only as a second language, but also in the mother tongue, in order to achieve business goals (Bargiela-Chiappini, Chakorn, Lay, Jung, Kong, Nair-Venugopal and Tanaka, 2007). However, regarding the second language, usually English, it has been found that workers are not usually prepared to face the most common business situations (Crossling and Ward, 2002).

Vivanco (2009), aware of the need for Spanish students of English to improve their oral fluency both in business and in everyday situations, conducted studies on teaching techniques aimed at improving oral skills, concluding that simulations of real situations in the classroom provide confidence and reduce social anxiety. This author also considers that, together with the oral expression, other aspects that enhance the image, persuasion, or reputation, such as pronunciation, quality and tone of voice, should not be neglected.

In this sense, Calle and Yanes (2010) and Yanes and Lourdes (2015), among others, show that the skill that worries students most with regard to their future professional development and communication in English are oral skills.

Thus, Angelini, García-Carbonell and Martinez (2015) conclude that the methodology of simulation and role play is in line with the development of communicative competence in language learning environments for specific purposes. As established by the European Higher Education Area, the Bologna plan, the Common European Framework of Reference for Languages and so on, the exercise of learning by doing is basic. This type of practice in the classroom, when acting out real-world situations, provides participants with the opportunity to improve language and professional skills adapted to the demands of the real world. 
The profile of future graduates from the university population who took part in this study is consistent with this approach and justifies the implementation of instructional simulation methodology for teaching and learning business and English.

The power of instructional simulation resides, in any case, in the reality of practice in which the participants are involved, in the analysis of the situation they face and in their decision-making, since "it is the environment that is simulated, - the company, the newsroom, the market place - but the behaviour is real" (Jones, 1995). In fact, simulation allows students to experiment with reality without unnecessary nerves; it prepares them to work together cooperatively and, therefore, it improves their skills and competencies in the English language.

According to Andreu, García Casas and Mollar (2005), all simulation must consist of three stages or essential parts: a) Briefing, b) Action and c) Debriefing.

In the first part or information phase (briefing) the objectives to be achieved are set, the working groups are organized and roles are assigned to each member of different groups; so before starting the simulation itself it is important that students understand what they will do and what instruments they have to analyze, discuss the situation and adopt the solutions that each group deems appropriate. In the first phase the lecturer must know how to propose a simulation that will encourage students to actively participate; some preliminary activities are proposed to help students remember, internalize and implement both the knowledge and the necessary skills through different written and / or audiovisual materials. Therefore, the teacher takes on the role of instructor.

The second phase is the action. Here, the students will face the situation around which the simulation revolves. The foreign language will be the leitmotif of these activities, an instrument that facilitates the task and helps students to communicate through the exchange of information, discussion, negotiation and decision-making. Here the teacher plays a role as a catalyst of the simulation process. The third and final phase is the debriefing: this is the evaluation and analysis of the simulation.

The evaluation phase or debriefing is as important as the simulation itself. It involves the return. An exercise in which students develop, with the help of the teacher, a process of constructive criticism of the decisions made to determine whether the problem has been solved successfully or not.

\section{Methodology}

\subsection{Problem statement}

The aim of the research was to analyse and evaluate the innovative use of a methodology that combines three elements, such as the use of English in the classroom through instructional simulation and new technologies. This methodology was applied in two different courses, both of them belonging to a University Degree in Business Administration. 
The two courses, both of them compulsory and imparted entirely in English at Abat Oliba University, were: Entrepreneurship (first term, 3 ECTS) and Strategic Management (second term, 6 ECTS). The assessment was carried out taking into account the students' point of view: once the courses were finished, a questionnaire was administered to the students, who were asked to answer on a voluntary basis.

All the students were non-English native speaking students who had been studying the language for a large number of years. However, their level of fluency varied, since very often they had not been able to practice the language in a real English environment. The objective was to analyse whether: 1., through the use of English in the class, combining all the skills (listening to the lecturer, classmates, videos,..., reading instructions, case studies, bibliography, writing assignments, blogs, news, oral presentation); 2., including mostly participative work such as simulations, games, presentations, role plays, etc.; and 3., with the use of new technologies (video making, blogs, games, prototypes...), the students acquired different skills, such as: structuring their speech better, communicating better, both written and orally, became more effective in teamwork, debating controversial issues, etc. The study also focused on whether, in general, the atmosphere in class improved, whether students acquired better skills for relating with others, whether attitudes towards working with people from different cultures were enhanced, etc. A total of 37 items were assessed.

When students participate in instructional simulation experiences, the student's perception is that the general learning process is enhanced; they learn also the English language in a better way, plus their motivation for learning increases.

Therefore, the new methodology using instructional simulation, new technologies and the English language resulted in a positive learning experience that has proved to be necessary for students who belong to the $\mathrm{Y}$ and $\mathrm{Z}$ Generations. Master classes based on theory, where students listen and take notes, can no longer remain the main methodology used in business administration studies.

\subsection{Procedure}

The two courses in which the new methodology was implemented were: Entrepreneurship (3 ECTS) and Strategic Management (6 ECTS), which form part of the Business Studies BA Degree. The sessions took place in conventional classrooms, with computers, and the ratio student/lecturer allowed for continuous mentoring and close monitoring. The students were required:

1. In the case of the Entrepreneurship Course: firstly, to form different teams (four to five people including male and female members and local people and foreigners). Then they had to find an opportunity in the market and start a new company; design a new product or service, take decisions in a simulation situation, estimate costs and sales, make a prototype whenever possible, build a blog and a promotional video, and finally, present the venture to a real capital risk team. The table below explains in detail how the simulation took place. 
Table 1. Explanation of the simulation experiment. Group 1. Entrepreneurship

\begin{tabular}{|c|c|c|}
\hline Phases & Contents & Implementation \\
\hline $\begin{array}{l}\text { Phase 1. Briefing } \\
\text { Lecturer together } \\
\text { with students. } \\
\text { First four weeks, } \\
\text { in class }\end{array}$ & $\begin{array}{l}\text { Need to start a new business by } \\
\text { students. Start-ups need to be } \\
\text { innovative, competitive, be born } \\
\text { global and require an investment } \\
\text { up to } 100,000 \text { euros. Also, the new } \\
\text { business needs to make money } \\
\text { while sleeping. Finally, it must } \\
\text { fulfil a need in the market that is not } \\
\text { being wholly satisfied. }\end{array}$ & $\begin{array}{l}\text { - Instructions are given on paper and } \\
\text { videos are used too. } \\
\text { • Examples of start-ups are given } \\
\text { through articles, personal experiences, } \\
\text { videos, etc } \\
\text { - Real entrepreneurs visit classroom } \\
\text { and share experiences. }\end{array}$ \\
\hline $\begin{array}{c}\text { Phase 2. Action } \\
\text { Following eight } \\
\text { weeks, mostly not } \\
\text { in class but out in } \\
\text { the field. }\end{array}$ & $\begin{array}{l}\text { Students must find and then develop } \\
\text { the business idea to turn it into a real } \\
\text { company following instructions. }\end{array}$ & $\begin{array}{l}\text { - Students need to study the market, } \\
\text { with a special emphasis on the practical } \\
\text { side. } \\
\text { • In terms of new technologies, the } \\
\text { must develop a prototype; } \\
\text { • Make a blog; } \\
\text { • Design a website; } \\
\text { - Use apps to make surveys; } \\
\text { • Make a video; } \\
\text { • Use social networks. }\end{array}$ \\
\hline $\begin{array}{c}\text { Phase 3. } \\
\text { Debriefing } \\
\text { One week. } \\
\text { It takes place in a } \\
\text { special classroom } \\
\text {-not the usual one. }\end{array}$ & $\begin{array}{l}\text { Students must deliver their new } \\
\text { business to a jury made up of } \\
\text { business angels and investors. }\end{array}$ & $\begin{array}{c}\text { - Students need to work in teams to } \\
\text { deliver the final project. } \\
\text { - They need to show all their } \\
\text { developments: web, blog, surveys, } \\
\text { videos, etc. } \\
\text { - The jury delivers and gives a prize to } \\
\text { best team. }\end{array}$ \\
\hline $\begin{array}{c}\text { Phase 4. } \\
\text { Evaluation } \\
\text { Last week. } \\
\text { Back in class. }\end{array}$ & $\begin{array}{l}\text { Lecturers and students, in a last } \\
\text { class, assess the whole process: } \\
\text { what has worked, what has not, } \\
\text { potential improvements. }\end{array}$ & $\begin{array}{l}\text { - Students need to reflect on the process } \\
\text { and find their own strengths and weak- } \\
\text { nesses: as individuals, as a team and } \\
\text { how the start-up would score. }\end{array}$ \\
\hline
\end{tabular}


2. In the case of strategic management: firstly, to form different teams (five people including male and female members and local people and foreigners); then to take part in a group role play (different managerial positions), design a strategic plan for a company in difficulties, study the financial situation, and develop a plan of action and communicate it to a panel of experts who evaluated the feasibility of such plan. The process, similar to that in the previous case, is explained in the table below:

Table 2. Explanation of the simulation experiment. Group 2. Strategic Management.

\begin{tabular}{|c|c|c|}
\hline Phases & Contents & Implementation \\
\hline $\begin{array}{l}\text { Phase 1. Briefing } \\
\text { Lecturer together } \\
\text { with students, and } \\
\text { occasionally a } \\
\text { business expert. } \\
\text { First two weeks, in } \\
\text { class }\end{array}$ & $\begin{array}{l}\text { Need to design a strategic plan for a } \\
\text { company in difficulties. Information is } \\
\text { given on the business (finance, human } \\
\text { resources, production, marketing, } \\
\text { sales, etc), and also on the sector. } \\
\text { Students make teams and play a role in } \\
\text { it: CEO, Financial Director, Marketing } \\
\text { Director, consultant, etc. }\end{array}$ & $\begin{array}{l}\text { - Instructions are given on paper } \\
\text { and videos are used too; } \\
\text { - Files with financial data are } \\
\text { included; } \\
\text { - A large quantity of data is } \\
\text { presented; } \\
\text { - Real business expert is invited, } \\
\text { who explains the case and the } \\
\text { sector situation. }\end{array}$ \\
\hline $\begin{array}{l}\text { Phase 2. Action } \\
\text { Following eight } \\
\text { weeks. } \\
\text { In class and in } \\
\text { workshops. }\end{array}$ & $\begin{array}{l}\text { Students must analyse the data, put it } \\
\text { in order, detect the main issues, make } \\
\text { a SWOT analysis, a PESTEL analysis, } \\
\text { Five Forces Model, etc. Finally, } \\
\text { propose a strategic plan to survive. }\end{array}$ & $\begin{array}{l}\text { - Students need to study the } \\
\text { business, with a special emphasis } \\
\text { on the practical side. } \\
\text { - They must make simulations with } \\
\text { the data: make scenarios and study } \\
\text { the results of different decisions. } \\
\text { - They must make a video and use } \\
\text { social networks. }\end{array}$ \\
\hline $\begin{array}{c}\text { Phase 3. } \\
\text { Debriefing } \\
\text { One week. } \\
\text { It takes place in a } \\
\text { special classroom } \\
\text {-not the usual one. }\end{array}$ & $\begin{array}{l}\text { Students must deliver their new } \\
\text { business to a panel of experts. }\end{array}$ & $\begin{array}{l}\text { - Students need to work in teams to } \\
\text { deliver the final project. } \\
\text { - They need to show all their } \\
\text { developments: video, scenarios, } \\
\text { simulations, final conclusions. } \\
\text { - The panel delivers and gives a } \\
\text { prize to best team. }\end{array}$ \\
\hline
\end{tabular}




\begin{tabular}{|c|c|c|}
\hline $\begin{array}{c}\text { Phase 4. } \\
\text { Evaluation } \\
\text { Last week. } \\
\text { Back in class. }\end{array}$ & $\begin{array}{c}\text { Lecturers and students, in a last class, } \\
\text { assess the whole process: what has } \\
\text { worked, what has not, potential im- } \\
\text { provements. }\end{array}$ & $\begin{array}{l}\text { - Students need to reflect on } \\
\text { the process and find their own } \\
\text { strengths and weaknesses: as } \\
\text { individuals, as a team and how } \\
\text { their proposal for a strategic plan } \\
\text { would score. }\end{array}$ \\
\hline
\end{tabular}

The methodology was developed during the 2014-15 academic year and implemented in 2015-16, in the first and second semesters. Lecturers evaluated students for each part of the methodology. To assess whether the objectives had been achieved, it was decided to make use of the survey methodology. To this end, a measuring instrument adapted from Angelini, García-Carbonell and Martinez (2015) was designed and delivered to the students after the end of the course.

There were 21 students in the Entrepreneurship Course and 42 in Strategic Management. The questionnaire was answered by 10 and 32 students respectively $(48 \%$ and $76 \%$ of the population).

The questionnaire was divided into five parts: first, some independent variables such as gender, age, course. Second, a self-evaluation of previous English level, before the courses took place; third, a self-evaluation of how the courses had had an impact on the different skills in English (oral, written, vocabulary...); fourth, the impact that the use of the new methodology in class had on use of English, attitude to learning, attitude to IT, skills in relating to others, interest in working with different cultures and so on. Finally, the questionnaire ended with three questions related to how they rated the three new experiences: taking classes in English, learning through simulation, and using IT in the classroom.

For the treatment and analysis of the data has been used IBM SPSS Statistics software, version 20.0. Have made the following analysis: descriptive univariate of all the variables involved, descriptive bivariate to explore the relationship between variables, normality tests, tests of parametric contrast and nonparametric to determine the significance of the differences found and ANOVAs to determine the significance of the differences found.

\section{RESULTS}

Concerning the two courses studied, about one third of the respondents were from the Entrepreneurship course, while two thirds were students of Strategic Management. Regarding gender, one third of the replies were from female students, while two thirds were from males, which corresponds to the gender makeup of the courses. The average age of the students was 22.7 years (which corresponds to the approximate average age of students in their fourth year). 
Figure 1. Students classified by course and gender.

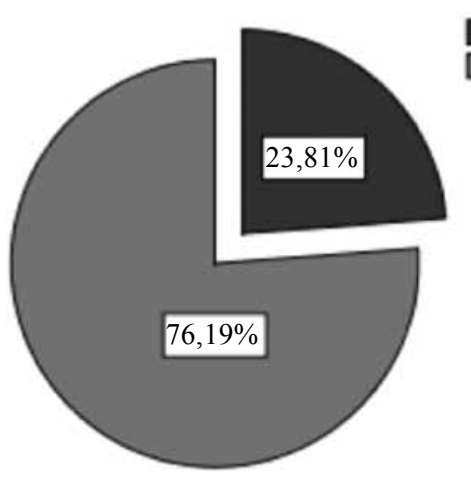

Entrepreneurship

Strategic Management

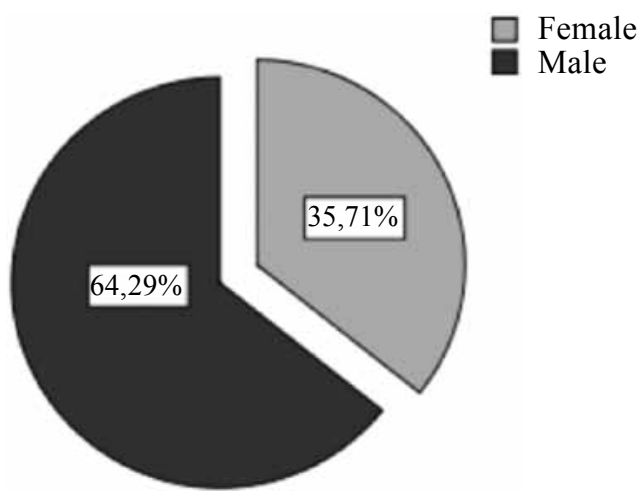

When asked whether they thought that English would be useful in their future professional life, the answer was unanimous, with $100 \%$ answering affirmatively.

The questionnaire asked about the English level students perceived they had previous to the course: in this sense, most students thought their command of English was "Medium" in listening comprehension, writing skills and speaking skills. While about $40 \%$ of the students felt their skills in English were "High", the other $60 \%$ felt it was between "Medium" and "Low".

Afterwards, the questionnaire asked about the impact the course had had on 37 different items. The range of possible answers went from 1 (very little impact) to 5 (large impact), and results were extremely encouraging. There are practically no results below 3 (just two: "Improvement in pronunciation", with 2.9 and "Attitude towards English has improved" with 2.8, but that is because their attitude towards learning English was already very positive).

The figure below shows how the development of English skills, together with the use of IT and the methodology based on real simulation resulted in other benefits such as an enhancement in class participation, negotiation skills, teamwork and even interest in other cultures. 
Figure 2. Summary of the three practices (use of English, use of IT and instructional simulation) and other benefits achieved.
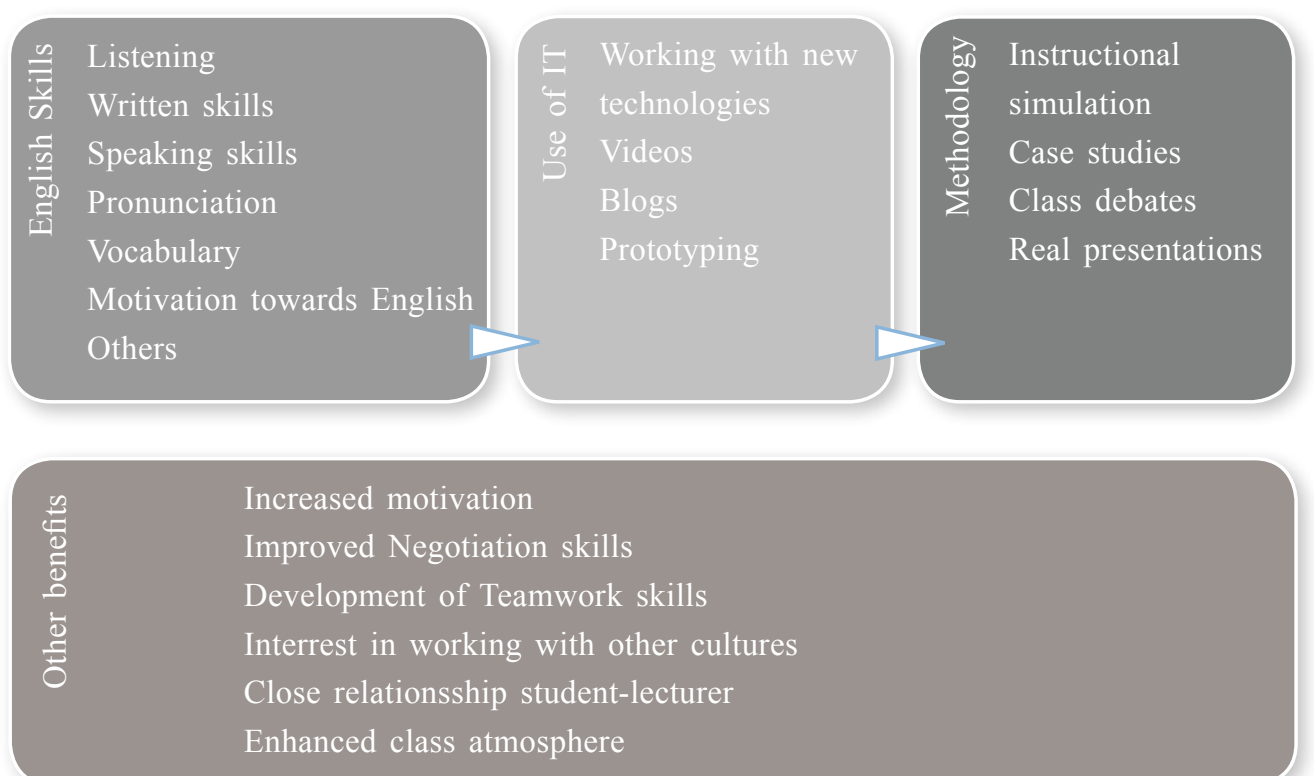

The following items received marks over 3.5: "I have enjoyed doing classes in English" got a 4.26. Since all the students perceived that English is going to be important for their future professional life, it is natural that they regarded doing classes in English as something with a high value added. They felt more confident to speak English after the course (3.5), they were highly motivated to learn English (3.9), teamwork was encouraged in class (3.7), student-lecturer relations were improved (3.6), the use of information and communication technologies in class was encouraged (3.6), and, generally, they felt comfortable in class before the rest of students, even if they had different levels of English (3.7). Students felt that the following methodologies had helped them improve their English: internal teamwork, class debates and presentations, preparation of final reports, and final team oral presentations, all of them rated over 3.5.

About the three last questions, students confirmed that: They enjoyed doing classes in English (4.3); they enjoyed learning through case studies (3.8) and they enjoyed using IT in the classroom (3.7). 
Table 3. Impact after the course. Lowest and highest values.

\begin{tabular}{|c|c|c|}
\hline Impact after the course. Ten lowest values (below 3.4) & Mean & SD \\
\hline My attitude towards English has changed & 2.83 & 1.228 \\
\hline Do you think your pronunciation has improved? & 2.98 & 1.239 \\
\hline Do you think your written skills have improved? & 3.10 & 1.265 \\
\hline Number of students in the class is appropriate & 3.17 & 1.010 \\
\hline My motivation to learn has increased & 3.19 & 1.174 \\
\hline The class atmosphere is better & 3.19 & 1.042 \\
\hline My negotiation skills have improved & 3.19 & 1.042 \\
\hline I now feel more interested in working with new technologies (simulations, etc.) & 3.24 & 1.322 \\
\hline Do you think your speaking skills have improved? & 3.36 & 1.186 \\
\hline Reading case studies has helped me to improve my English & 3.36 & 1.008 \\
\hline Impact after the course. Ten highest values (above 3.6) & Mean & SD \\
\hline The use of Information and Communication Technologies is encouraged & 3.60 & 0.964 \\
\hline Class debates and presentations have helped me improve my English & 3.60 & 0.939 \\
\hline Student-Lecturer relations have improved & 3.62 & 0.987 \\
\hline The preparation of the final report has helped me improve my English & 3.64 & 0.983 \\
\hline Teamwork is encouraged in class & 3.67 & 1.028 \\
\hline I feel comfortable in class before students with different levels of English & 3.69 & 1.158 \\
\hline I enjoyed using IT in class & 3.69 & 1.199 \\
\hline The final team oral presentation helped me improve my English & 3.76 & 1.078 \\
\hline I have enjoyed learning through case studies & 3.76 & 1.185 \\
\hline I am highly motivated to improve my English & 3.88 & 1.109 \\
\hline I have enjoyed doing classes in English & 4.26 & 1.037 \\
\hline
\end{tabular}


Table 4. Mann-Whitney U contrast between "Reading comprehension" and "Speaking skills" and level before and after the courses.

\begin{tabular}{|c|c|c|c|c|c|c|c|c|c|c|c|c|}
\hline & \multicolumn{6}{|c|}{$\begin{array}{c}\text { Reading comprehension } \\
\text { (written texts) }\end{array}$} & \multicolumn{6}{|c|}{ Speaking skills } \\
\hline & \multirow{2}{*}{$\begin{array}{l}\text { High } \\
\text { Md }\end{array}$} & \multirow{2}{*}{$\begin{array}{c}\begin{array}{c}\text { Me- } \\
\text { dium }\end{array} \\
\text { Md }\end{array}$} & \multirow{2}{*}{$\chi^{2}$} & \multirow[t]{2}{*}{$\mathrm{gl}$} & \multirow{2}{*}{$\mathrm{p}$} & \multirow{2}{*}{$\begin{array}{c}\text { Cramér's } \\
\text { V }\end{array}$} & High & Medium & \multirow{2}{*}{$\chi^{2}$} & \multirow[t]{2}{*}{ gl } & \multirow{2}{*}{$\mathrm{p}$} & \multirow{2}{*}{$\begin{array}{c}\text { Cramér's } \\
\text { V }\end{array}$} \\
\hline & & & & & & & Md & $\mathrm{Md}$ & & & & \\
\hline $\begin{array}{l}\text { Do you think } \\
\text { your listening } \\
\text { comprehension has } \\
\text { improved? }\end{array}$ & & & & & & & 2 & 4 & 10.33 & 2 & .006 & 0.70 \\
\hline $\begin{array}{l}\text { Do you think your } \\
\text { written skills have } \\
\text { improved? }\end{array}$ & 2 & 4 & 6.59 & 2 & .037 & 0.56 & 2 & 4 & 8.85 & 2 & .012 & 0.64 \\
\hline $\begin{array}{l}\text { Do you think your } \\
\text { speaking skills } \\
\text { have improved? }\end{array}$ & & & & & & & 3 & 4 & 7.49 & 2 & .024 & 0.60 \\
\hline $\begin{array}{l}\text { Do you think } \\
\text { your skills in } \\
\text { communicating } \\
\text { ideas have } \\
\text { improved? }\end{array}$ & & & & & & & 3 & 4 & 6.93 & 2 & .031 & 0.57 \\
\hline $\begin{array}{l}\text { Do you feel more } \\
\text { fluent when you } \\
\text { speak? }\end{array}$ & & & & & & & 3 & 4 & 6.87 & 2 & .032 & 0.57 \\
\hline $\begin{array}{l}\text { Do you feel more } \\
\text { confident when } \\
\text { you need to speak } \\
\text { in English? }\end{array}$ & & & & & & & 3 & 4 & 6.42 & 2 & .040 & 0.55 \\
\hline $\begin{array}{l}\text { Do you think you } \\
\text { have achieved a } \\
\text { richer vocabulary? }\end{array}$ & & & & & & & 3 & 4 & 6.11 & 2 & .047 & 0.53 \\
\hline $\begin{array}{l}\text { Do you think your } \\
\text { pronunciation has } \\
\text { improved? }\end{array}$ & 3 & 4 & 6.20 & 2 & .045 & 0.54 & & & & & & \\
\hline $\begin{array}{l}\text { Do you think your } \\
\text { overall skills in } \\
\text { the use of English } \\
\text { have improved? }\end{array}$ & & & & & & & 3 & 4 & 8.81 & 2 & .012 & 0.64 \\
\hline $\begin{array}{l}\text { I have enjoyed } \\
\text { doing classes in } \\
\text { English }\end{array}$ & 5 & 4 & 7.11 & 2 & .028 & 0.58 & & & & & & \\
\hline
\end{tabular}


An analysis was carried out between: level in English (before and after) both in Reading and Speaking, and with several indicators related to level in English (vocabulary, pronunciation, overall skills in English, etc.) after the impact of the course using instructional simulation and new technologies in class.

- Regarding "Reading comprehension", the data show that students with a previous low-medium level of English improved their written skills and their pronunciation and that they enjoyed doing the simulations in English, with a moderate intensity relation, according to the Cohen criteria (Cramér's V $=0.56 ; 0.54 ; 0.58$, respectively.

- Concerning "Speaking Skills" and the indicator "Do you think your listening comprehension has improved?", the results show a statistically significant relation between both variables $(\chi 2=10.33 ; \mathrm{gl}=2 ; \mathrm{p}=0.006)$ with a high intensity relation according to the Cohen criteria (Cramér's $V=0.70$ ).

Thus, the empirical evidence indicates a statistically significant relationship between "Speaking Skills" and the following indicators: "Do you think your written skills have improved?", "Do you think your speaking skills have improved?" and "Do you think your overall skills in the use of English have improved?" with a high intensity ratio according to the Cohen criteria (Cramér's V $=0.64 ; 0.60 ; 0.64$, respectively). Students with lower levels of English consider their general skills in both written and spoken English improved.

The most detailed description of the comparative analysis of pre and post-treatment scores obtained in the overall assessment of the variable "Speaking Skills" and the rest of the variables in the experimental groups are shown fully in Table 4; it can be stated that students with a previous medium-low level improved their English through their learning process more than their fellow students who started with a higher English level.

\section{Conclusions}

Tools such as instructional simulations in business environments are becoming educational strategies broadly accepted thanks to the potential they offer to increase students' motivation and commitment (Angelini, García-Carbonell and Martinez, 2015).

In fact, instructional simulation introduces students into a scenario that mimics real life circumstances. The participants, divided into teams, carry out the analysis of this reality, negotiate positions, take decisions, resolve issues and reflect on the experience. In this way, simulation methodology facilitates the acquisition of expertise while enabling interacting, communicating, leading, negotiating and working in teams, in real contexts. This new methodology based on learning by doing is basic, and, this type of practice in the classroom, role-playing real-world situations, provides participants with the opportunity to improve language and professional skills adapted to the demands of the real world.

The aim of this research was to analyse and evaluate the innovative use of a methodology that combined three elements, such as the use of English in the classroom through instructional simulation and the use of new technologies. This methodology was applied in two different courses, both of them belonging to a University Degree in Business Administration. 
The two courses, both of them compulsory and imparted entirely in English at Abat Oliba University, were: Entrepreneurship (first term, 3 ECTS) and Strategic Management (second term, 6 ECTS). The assessment was carried out taking into account the students' point of view: once the courses were finished, a questionnaire was administered to the students, who were asked to reply on a voluntary basis. A total of 42 replies were collected.

Results were highly encouraging. Students confirmed that they enjoyed doing classes in English (rated 4.3/4), they enjoyed learning through simulations (3.8/5) and they also enjoyed using new technologies in the classroom (3.7/5).

Students felt that the following methodologies had helped them improve their English: internal teamwork, class debates and presentations, preparation of final reports, and final team oral presentations, all of them rated over 3.5/5.

Apart from learning how businesses work in real scenarios, and improving their English skills, other major benefits were achieved: their motivation for learning increased, they developed some additional negotiation skills and they enhanced their capability to work in teams (Aranda, Sánchez and Djundubaev, 2016). Moreover, the class atmosphere was enhanced, and a closer relationship was created between lecturers and students. Last but not least, students found that they were more interested in working with people from different cultures.

We can conclude, then, that the use of instructional simulation in business courses that are imparted in English, reinforced with the use of new technologies, represents a winning mix, achieving surprising positive effects in both the learning process and results.

\section{REFERENCES}

Andreu, A., García Casas, M. and Mollar, M. (2005). "La simulación y juego en la enseñanza y aprendizaje de la lengua extranjera", en Cuadernos Cervantes, XI, 55: 34-38.

Angelini, L., García-Carbonell, A. and Martínez Alzamora, N. (2015). "Estudio cuantitativo sobre la simulación y el juego en la producción oral en lengua inglesa", en Revista de Docencia Universitaria, 13, 2: 285-306.

Aranda, D. A., Sánchez, O. F. B. and Djundubaev, R. (2016). "Efectos de los juegos de simulación de empresas y Gamification en la actitud emprendedora en enseñanzas medias", en Revista de educación, 371: 126-149.

Bargiela-Chiappini, F., Chakorn, O. O., Lay, G. C. C., Jung, Y., Kong, K. C., Nair-Venugopal, S. and Tanaka, H. (2007). "Eastern voices: enriching research on communication in business: a forum", in Discourse and Communication, 1, 2: 131-152.

Blasco, F. (2000). Teoría y aplicación de los métodos de aprendizaje en las Ciencias Empresariales: análisis comparativo entre el Método del Caso y el Juego de Simulación de Empresa. EU Empresariales, Seminario de Marketing, Madrid, Universidad Complutense de Madrid.

Brookfield, S. D. (1983). Adult Education and the community. Milton Keynes: Open University Press.

Calle, C. and Pomposo, L. P. (2010). Estudio de la eficacia de actividades prácticas en un aula de inglés de negocios para mejorar las destrezas orales. In Analizar datos $>$ Describir variación [Recurso electrónico]: Analysing data $>$ Describing variation (p. 42). Servicio de Publicaciones.

Clemente, M. I. R. and Pérez, M. D. C. C. (2013). Adquisición de competencias a través de la simulación y juego de rol en el área contable. Estudios sobre el Mensaje Periodístico, 19: 419-428. 
Crawford, C. (2003). Subjectivity and Simulation. Serious Games: Improving Public Policy through Game-based Learning and Simulation. Washington, DC: Woodrow Wilson International Center for Scholars, Foresight and Governance Project.

Crossling, G. and I. Ward. (2002). "Oral communication: the workplace needs and uses of business graduate employees", in English for Specific Purposes, 21: 41-57.

De Miguel, M. (2006a). "Metodologías para optimizar el aprendizaje. Segundo objetivo del Espacio Europeo de Educación Superior", en Revista Interuniversitaria de Formación del Profesorado, 20, 3: 71-91.

De Miguel, M. (2006b). Metodologías de enseñanza y aprendizaje para el desarrollo de competencias. Madrid, Alianza Editorial.

Domínguez, A., Saenz-de-Navarrete, J., De-Marcos, L., Fernández-Sanz, L., Pagés, C. and Martínez-Herráiz, J. J. (2013). "Gamifying learning experiences: Practical implications and outcomes", in Computers and Education, 63: 380-392.

García-Carbonell, A., Watts Hooge, F. I. and Andreu Andrés, M. A. (2012). "Simulación telemática como experiencia de aprendizaje de la lengua inglesa", en Revista de Docencia Universitaria, 10(3), 301-323.

Jones, K. (1995). Simulations. A Handbook for teachers and trainers. London: Kogan Page, Ltd.

Pomposo, L. (2015). Análisis de necesidades y propuesta de evaluación en línea de la competencia oral en inglés en el mundo empresarial. Tesis doctoral. Universidad Nacional de Educación a Distancia. http://e-spacio.uned.es/fez/view/tesisuned:Filologia-Mlourdespomposo

Romero, M. (2010). "El aprendizaje experiencial y las nuevas demandas formativas", en Revista de antropología experimental, 10, 8: 89-102.

Ros, M. I. and Conesa, M. D. C. (2013). "Adquisición de competencias a través de la simulación y juego de rol en el área contable”, en Estudios sobre el Mensaje Periodístico, 19: 419-428.

Santos, N. B., Alarcón, M. M. H. and Pablo, I. M. (2016). "Fillers and the development of oral strategic competence in foreign language learning", in Porta Linguarum: revista internacional de didáctica de las lenguas extranjeras, (25), 191-201.

Vivanco, V. (2009). "Holistic versus communicative approach in assessing oral production in English", in Revista Electrónica de Investigación y Evaluación Educativa, 15, 2: 1-13. 